Wright State University

CORE Scholar

Nursing Faculty Publications

Nursing

2015

\title{
System Base Practice as a Public Health Nursing Workforce Competency Requirement
}

Ann M. Stalter

Wright State University - Main Campus, ann.stalter@wright.edu

Follow this and additional works at: https://corescholar.libraries.wright.edu/nursing_faculty

Part of the Nursing Commons

\section{Repository Citation}

Stalter, A. M. (2015). System Base Practice as a Public Health Nursing Workforce Competency

Requirement. Review of Public Administration and Management, 3, 1000165.

https://corescholar.libraries.wright.edu/nursing_faculty/245

This Article is brought to you for free and open access by the Nursing at CORE Scholar. It has been accepted for inclusion in Nursing Faculty Publications by an authorized administrator of CORE Scholar. For more information, please contact library-corescholar@wright.edu. 


\section{and Management}

\section{System Base Practice as a Public Health Nursing Workforce Competency Requirement}

\section{Ann M. Stalter}

Associate Professor, RN-to-BSN Director, Wright State University, Ohio, USA

\section{Commentary}

This is an exhilarating time to be in public health! Internationally, the digital world has created an environment for the economic security needed to protect health and promote healing of all mankind. Globalization allows scientists to treat and track diseases in ways that have never been possible. In the United States (U.S.), the federal mandate for equal access to health care has opened a plethora of imaginary and tangible boundaries of which were antecedents to just about every-ism known to public health providers. With this exciting reform comes the need for workforce awareness and new ways of thinking and performing jobs. Competency based curricula appear to be addressing some of the transformation needed to advance a responsive public health workforce.

Nursing curricula promote fundamental competencies mastery using evidence based practice to maintain quality and safety. Recently, market conditions advance a baccalaureate nursing education for entry to professional practice and demand well-designed online programs. U.S. universities offering nursing degrees are working diligently to revise content and to redesign programs in order to expand distance learning opportunities and to poise nurses to lead health through the 21 st century. The purpose of this commentary is to recommend to all public health and curriculum designers that in order effectively contribute to the public health workforce, all nurses need to understand system based theory.

The recommendation arises from two underlying issues: the need for relevant general education and experiences that result in self-assurance. Historically, a liberal education in nursing has been comprised of courses in English and communication, sociology, psychology, basic mathematics, chemistry, biology and humanities such as art, music, or religion. Advanced sciences have been considered anatomy, physiology, microbiology, pathophysiology, pharmacology and nutrition. Typically, once general education courses are successfully completed, basic nursing courses offer students' knowledge and skills to promote health, prevent disease or provide care for individuals and families. Since the 1950's community/public health has been hallmark to baccalaureate nursing practice. During community/public health nursing courses, nurse educators teach students to make an aggregate leap in managing care. Public health nursing courses have provided students the opportunity to gain insight about social determinants of health, and how policy impacts access.

Since the adoption of the Patient Protection and Affordable Care Act (PPACA) [1], the reformed health care system is much more complex. To understand a fraction of the magnitude of its complexity, consider that in 2011, the Institute of Medicine indicated that an increased workforce of baccalaureate-prepared nurses, nurse practitioners, and doctorally-prepared nurses is needed by 2039 to care for a projected 400 million U.S. citizens (Population Reference Bureau) [2]. Of these, 10,000 people are reaching 65 years of age every day starting January 1, 2010 until December 31, 2039 (Pews Research Center) [3]. By 2020, 1 million new nurses must be ready to care for the masses of elderly that will dwell and receive care in community settings (Morton) [4]. In addition to a growing geriatric population is an increase in immigrants to the health care system. Data suggests that one in five Americans do not speak English (American Community Survey) [5] and future projections are that Spanish speaking Latinos will comprise $87 \%$ of population growth (Taylor) [6]. So, nursing education should consider Spanish as a second language requirement. Because of the complexities of the health care system, nurses' skills need to expand beyond aggregates to negotiate and navigate interrelated services, networks, and processes in order to direct care; there is a need for a systems leap. That is, as public health advances in the U.S. and demography changes, the need for nursing to adopt system level changes is exceedingly important. According O' Neil [7], systems thinking is essential for the delivery of safe care across complex health care systems.

The scientific underpinnings for systems level thinking are found in seminal papers on topics such as General Systems Theory (von Bertalanffy) [8], Planned Approach (Lewin) [9], Economic Analysis (Boulding) [10], complexity theories (Rescher) [11], and chaos theory (Lorenz) [12]. Pre-requisite systems-leveling thinking involves applied logic, understanding laws of physics, and advanced technologies and mathematics--enough to predict outcomes based on pattern recognition (Cheek and Jones; Fraser and Greenhalgh) $[13,14]$.

The Essentials of Baccalaureate Education for Professional Nursing Practice (BSN Essentials I-IX) guides undergraduate nursing education (American Association of Colleges of Nursing [AACN]) [15]. It was written prior to the PPACA (2010) and limits general education to basic math, science, English and arts/humanities. BSN Essential I Liberal Education for Baccalaureate Generalist Nursing Practice, indicates that nurses form the "basis for intellectual and practical abilities for nursing practice" and "for engagement with" local and global communities (AACN, 2009, p. 11) via skills of inquiry, analysis, critical thinking, and communication" through the use of technologies, team work, and inter-professional problem solving" (AACN, 2009, p. 11). BSN Essential I reinforces the study of foreign language because it encourages the "appreciation for cultural and ethnic diversity" (AACN, 2009, p. 11).

BSN Essential II Basic Organizational and Systems Leadership for Quality Care and Patient Safety describes specifically that baccalaureate-prepared nurses should graduate with the "knowledge and skills in leadership, quality improvement, and patient safety that

*Corresponding author: Stalter AM, Associate Professor, RN-to-BSN Director Wright State University, CoNH, 136UH, 3640 Col. Glenn HWY, Dayton, Ohio 45435, USA, Tel: 937-371-9946; Fax: 937-775-4571; E-mail: ann.stalter@wright.edu

Received June 17, 2015; Accepted August 26, 2015; Published August 28, 2015

Citation: Stalter AM (2015) System Base Practice as a Public Health Nursing Workforce Competency Requirement. Review Pub Administration Manag 3: 165. doi:10.4172/2315-7844.1000165

Copyright: @ 2015 Stalter AM. This is an open-access article distributed under the terms of the Creative Commons Attribution License, which permits unrestricted use, distribution, and reproduction in any medium, provided the original author and source are credited. 
is necessary to provide high quality care" (AACN, 2009, p. 3) and an "awareness of complex organizational systems" (p.14). Underscoring the need for safety across systems and populations cannot be understated. Phillips et al. [16] describe systems-level thinking as an educational process of moving from high reliance on authority to high interdependence and from awareness to application. The process presumes that critical reasoning and mastery over patient centered care, teamwork and collaboration, evidence based practice, informatics, quality improvement and safety (Cronenwett) [17] before higher level functioning within systems can occur. BSN learning experiences that focus on develop system-wide practice changes that improve the quality of health care delivery increase awareness and effective functioning post-graduation are essential. Examples include accountability for safe delivery of care in a variety of community and population based settings; inter-professional team coordination; care navigation; applying quality improvement processes to implement safety initiatives; monitoring and analysing outcomes; and, employing principles of quality improvement, health care policy and cost-effectiveness. But in order to prepare graduates for such experiences, they must be present within settings that expose them to policy decisions such as, legislative activities at state houses; exposure to immigration services; and, the administration of government programs. Assignments where students participate in lobbying, board room meetings, disaster planning meetings, national or regional level inter-professional forums, and reviewing articles from professional journals aimed at international public health audiences are vital. Assignments should be fieldwork based such as study abroad programs where they complete community and cultural assessments; local case management through acute care discharge planning, home health and rehabilitation admission, and other care coordination experiences where multiple perspectives and inter-professional teams contribute to patient care plans and outcomes.

BSN Essentials III-IX focus on evidence-based practice; information and technology; and, health care policy, finance and regulatory environments. In addition, the BSN Essentials emphasize inter-professional communication and collaboration to improve patient health outcomes, and clinical prevention for population health. The generalist baccalaureate nursing practice is reinforced by professionalism and professional values. Overall, each of the BSN Essentials III-IX is experienced in the context of complex systems.

This recommendation is made because, not all nursing programs use the BSN Essentials to design and implement curricula. Nursing programs awarding associate degrees and diplomas do not employ BSN Essentials and only baccalaureate programs that are accredited by the AACN must address BSN Essential II. Currently, systems- based thinking and practice are not addressed by other credentialing agencies. The BSN Essentials were developed in response to the three series Institute on Medicine reports, aimed at improving quality and safety in nursing. Thus, programs employing BSN Essentials infer improved quality and safety outcomes, and those employing BSN Essential II prepare nurses to lead quality and safety across complex delivery systems. Future populations need nurses who have system level awareness and expertise. At minimum, the recommendation deserves debate among nurse educators and those interested in the quality of the public's health.

\section{References}

1. http://www.gpo.gov/fdsys/pkg/PLAW-111publ148/pdf/PLAW-111publ148.pd

2. http://www.prb.org/Publications/Articles/2008/us400million.aspx

3. http://www.pewresearch.org/daily-number/baby-boomers-retire/

4. http://www.newsday.com/opinion/oped/we-ll-need-1-million-new-nursesby-2020-1.10600358

5. https://www.census.gov/hhes/socdemo/language/data/acs/Shin_Ortman FFC2011_paper.pdf

6. Taylor P (2014) The next America: Boomers, millennials, and the looming generational showdown. PublicAffairs, NewYork.

7. O’Neill RM (2015) Systems-centered $\AA$ management: A brief review of theory practice and research. Review Public Administration and Management 3:144.

8. Bertalanffy LV (1937) Das Gefüge des Lebens. Leipzig. BG Teubner, Germany

9. Lewin K (1947) Group decisions and social change. In: Newcomb TM, Hartley EL (eds) Reading in Social Psychology. Henrry Holt, New York.

10. Boulding KE (1961) Some difficulties in the concept of economic input. In Output, Input, and Productivity Measurement. Princeton University Press, Princeton.

11. Rescher N (1996) Complexity: a philosophical overview. Transaction Publishers, New York.

12. Lorenz E (1979) Predictability: does the flap of a butterfly's wing in brazil set of a tornado in Texas?. Address at the American Association for the Advancement of Science, Washington, DC

13. Cheek J, Jones J (2003) What nurses say they do and need: implications for the educational preparation of nurses. Nurse Educ Today 23: 40-50.

14. Fraser SW, Greenhalgh T (2001) Coping with complexity: Educating fo capability. BMJ 323: 799-803.

15. http://www.aacn.nche.edu/publications/order-form/baccalaureate-essentials

16. Phillips J, Stalter AM, Dolansky M, McKee G (2015) Fostering future leadership in quality and safety in health care through systems thinking. Journal of Professional Nursing.

17. Cronenwett L, Sherwood G, Barnsteiner J, Disch J, Johnson J, et al. (2007) Quality and safety education for nurses. Nurs Outlook 55: 122-131.
Citation: Stalter AM (2015) System Base Practice as a Public Health Nursing Workforce Competency Requirement. Review Pub Administration Manag 3 : 165. doi:10.4172/2315-7844.1000165

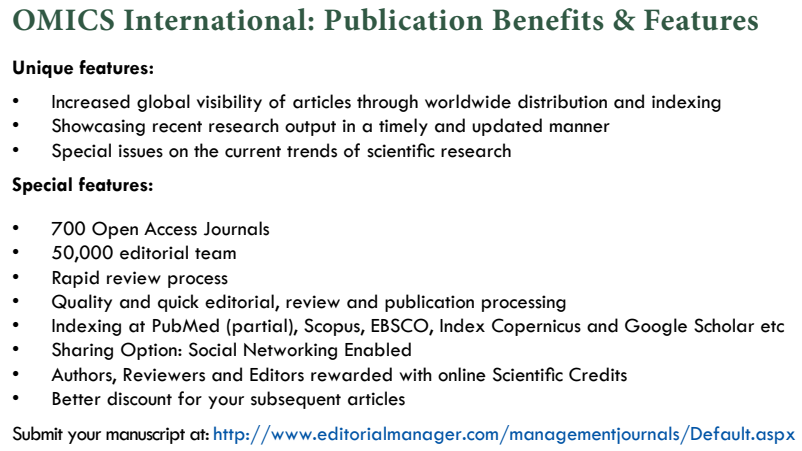

